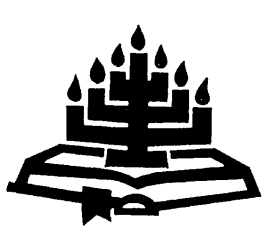

\title{
Praxis pietatis. teologies nagedink oor aspekte van die spiritualiteit van Augustinus $^{1}$
}

\author{
J.H. van Wyk
}

Navorser: Skool vir Kerkwetenskappe

Potchefstroomkampus

Noordwes-Universiteit

POTCHEFSTROOM

Epos: amievw@intekom.co.za

\begin{abstract}
Praxis pietatis. reflections on aspects of the spirituality of Augustine

Especially since the rise of postmodernism by the end of the twentieth century - with its sharp criticism on the frigidity of the rationalism of modernism - theology is much more concerned with what is called spirituality and "praxis pietatis", also within reformed circles. In this article the author investigates the contribution of the great church father from North Africa, Augustine, particularly because the reformed tradition (via Calvin) feels such a strong affinity with the theology of Augustine. It is intriguing to investigate how Augustine tried to unite in his person the polar opposites of rationality and spirituality, contemplation and action and to bring them into a synthesis. Not for nothing was Augustine described by A. von Harnack as "the first modern man."2
\end{abstract}

$1 \quad$ Hierdie tema is in 'n gewysigde vorm in 'n Nederlandse boek hanteer (vgl. Van Wyk, 2008:254-266). Dit het ook gedien as basis vir 'n voordrag tydens die opening van die Teologiese Skool Potchefstroom op 12 Februarie 2008.

2 Vergelyk Van der Zwaag, 1993:6 (geresenseer deur J. van Oort). 


\section{Opsomming}

\section{Praxis pietatis: teologiese nadenke oor aspekte van die spiritualiteit van Augustinus}

Veral sedert die opkoms van die postmodernisme teen die einde van die twintigste eeu - met sy skerp kritiek teen die koue rasionalisme van die modernisme - word in die teologie al hoe meer aandag gegee aan wat genoem word spiritualiteit en "praxis pietatis", ook binne die gereformeerde tradisie. In hierdie artikel ondersoek die outeur die bydrae van die groot kerkvader uit Noord Afrika, Augustinus, in hierdie verband, juis omdat die gereformeerde tradisie (via Calvyn) so 'n sterk aansluiting vind by die teologie van Augustinus. Dit is boeiend om na te gaan hoe Augustinus gepoog het om die pole van rasionaliteit en spiritualiteit, aksie en kontemplasie in hom as persoon te verenig en tot ' $n$ sintese te bring. A. von Harnack het Augustinus nie verniet as "die eerste moderne mens" beskryf nie.

\section{Inleiding}

Dit is duidelik dat daar gedurende die laaste aantal dekades in ' $n$ besondere mate op die tema van spiritualiteit gefokus is - ' $n$ veelsinnige term soos later sal blyk. Natuurlik is dit nie 'n volkome nuwe tema nie, so asof die vroeë kerk en die kerk in die Middeleeue, asook in later tye nooit hieroor nagedink het nie. Ek is van mening dat ons reeds by die groot kerkvader en biskop uit Noord-Afrika, Aurelius Augustinus (354-430), veel oor hierdie onderwerp kan leer.

Dat daar in so 'n kort artikel noodwendige seleksie moet plaasvind, spreek vanself. Hoe anders kan daar iets sinvol gesê word oor een van die grootste kerkvaders van alle tye wat ongeveer vyf miljoen woorde nagelaat het?3 Sy biograaf, Possidius (1988:80; vita 18.9), het gesê dat Augustinus soveel gepubliseer het dat selfs 'n student kwalik die energie sal kan voortbring om al sy geskrifte te lees en daarmee vertroud te raak. Isidorus van Seville het aangevoer dat wie beweer dat hy alles gelees het wat Augustinus geskryf het, 'n leuenaar moet wees (O'Donnell, 2005:135).

3 Vergelyk O'Donnell $(2005: 5,35,202,318)$. Dit kom neer op 'n boek van ongeveer 300 bladsye jaarliks vir 40 jaar (O'Donnell, 2005:136). Ongeveer 600 van sy preke het bewaar gebly. Augustinus het elke Saterdag en Sondag gepreek, ook op alle feesdae, tydens die liturgiese jaar soms elke dag, sommige dae verskillende kere en met 'n enkele viering soms verskillende kere. Geleerdes skat dat hy tussen 4 000-6 000 keer gepreek het (vgl. sermo 198376(A); kyk Van Zaalen et al., 2001:11). O'Donnell (2005:133) bereken dit op 8000. 
Die keuse om oor die spiritualiteit van Augustinus 4 te skryf, is eenvoudig: sy invloed op die teologie in die algemeen en spiritualiteit in die besonder was enorm. Hy word wêreldwyd as een van die grootste teoloë van alle tye beskou.

\section{Spiritualiteit as teologiese tema}

Navorsers wys daarop dat een van die hoofkenmerke van die postmoderne tyd in die verset teen die rasionalisme, tegnokrasisme en funksionalisme van die modernisme sedert die agtiende eeu gevind kan word - vandaar die klem op spiritualiteit (vgl. Schrama, 1999:239-265).

In Suid-Afrika ${ }^{5}$ sowel as in die Westerse wêreld $\mathbf{6}$ is oor die tema van spiritualiteit navorsing gedoen en die literatuur op hierdie gebied het haas onoorsigtelik geword.

Die begrip spiritualiteit is 'n veelkleurige begrip met 'n reeks betekenisskakerings. Daar bestaan ook 'n wye verskeidenheid spiritualiteite soos byvoorbeeld die mistieke spiritualiteit van die Oosterse Kerk, die sakramentele spiritualiteit van die Westerse Katolieke Kerk, die ervaringspiritualiteit van die anabaptisme en die charismatiese beweging en die meer nugter spiritualiteit van die gereformeerde tradisie (vgl. Jonker, 1989:291; Velema, 1990:54-59; Kourie \& Kretzschmar, 2000:23-29; breedvoerig in Waaijman, 2000).

Uiteraard is daar in die verskillende spiritualiteitstipes, naas verskilpunte, ook bepaalde raakpunte, omdat dit vir Christene telkens oor die drie-enige God gaan. Dit is dus vanselfsprekend dat dit by ' $n$ onderwerp soos spiritualiteit oor die mens se verhouding tot God, sy geloof in God en sy lewe voor die aangesig van God, sy Godsvrug en vroomheid behoort te gaan. Dit gaan oor die mens se lewens-

$4 \quad$ Volledige bibliografiese gegewens van die werke van Augustinus is onder andere te vind in Fitzgerald (1999).

5 Vergelyk slegs Conradie (2006a; 2006b), De Villiers et al. (2006), Dreyer (1998), Jonker (1989), Kourie en Kretzschmar (2000), Kretschmar (1996), Louw (2005), Nicol (2002), Nolan (1982), Oostenbrink en Lotter (1999), Smit (1988; 1989), Snyman (1997), Venter (1998), De Villiers (2008), Van der Walt (2009) en Lombaard (2009).

6 Vergelyk Aumann (1985), Beumer (1990), Holmes (1981), Jones et al. (1986), Maris (1994), McGrath (1999), Pannenberg (1986), Ramey en Johnson (1992), Rice (1991), Van den Berg en Süss (2006), Van 't Spijker et al. (1993), Velema (1990), Waaijman (2000) en Howard (2008). 
oriëntering, lewensbeskouing, lewenshouding en lewenswandel, oor die sakrale en die sekulêre, die innerlike en die uiterlike, denke en doen, woorde en dade, kontemplasie en aksie, ortodoksie en ortopraksie (Kretzschmar, 1996:63-75). Daar word al hoe meer op 'n holistiese benadering gefokus wat die totale lewe van die mens voor die aangesig van God (coram Deo) omvat en wat 'n lewe voor die mense (coram hominibus) en in die natuur insluit as skepping van God.

Die ware spirituele mens is nie iemand wat hom/haar aan die aarde en die daaglikse gang van sake onttrek nie, maar juis iemand wat midde-in die stroom van die lewe die beeld van God uitleef en Christus navolg. Die lewe in die binnekamer, die kerk en die wêreld vorm een integrale lewe, mét God, vóór God, volgens sy Woord en wil. Die pietas kry sodoende in die praksis gestalte (Velema, 1990:12). ${ }^{7}$

\section{Die spiritualiteit van Augustinus}

In hierdie beknopte artikel kan slegs enkele belangrike aspekte van die spiritualiteit van die kerkvader uitgelig en toegelig word. In hierdie verband is dit noodsaaklik om daarmee rekening te hou dat die lewe en denke van Augustinus 'n bepaalde ontwikkelingsgang deurgemaak het, wat die volgende insluit: sy (verloopte) jeugjare; die deurslaggewende invloed van sy godvresende moeder, Monnica; sy aanvanklike aansluiting (vir 9 jaar) by die Manicheërs; 8 sy lewe saam met 'n (naamlose) konkubine vir veertien jaar (371-385), 'n verhouding wat in Milaan abrup beëindig word; die deurlopende invloed van die Neo-Platonisme; sy bekering in 'n tuin in Milaan (386); sy kort priesterskap (391-396); en sy lewe as biskop en pastor in Hippo Regius in Noord-Afrika (396-430), waaronder sy aanvanklike stryd met die Donatiste en later die Pelagiane. In kort: sy soeke na (en vind van) die waarheid, die goeie, die geluk, die ware rus - wat hy uiteindelik in God en in Christus vind. Augustinus lê gedeeltelik getuienis hiervan af in sy beroemde boek Confessiones (397-401) (conf.), terwyl sy vriend Possidius die verhaal met 'n lewensbeskrywing van Augustinus sou voltooi.

7 Dit is opvallend dat die begrip eusébeia in die Nuwe Testament op 'n bepaalde manier van lewe dui (Foerster, 1985:1012.)

8 Van Oort (2005:28-29) wys daarop dat selfs ná Augustinus se breuk met die Manicheïsme, die gnostiese komponent die katolieke nog permanent begelei het. Augustinus gee ook in sy Confessiones 'n karikatuur van sy spirituele dwaling (Van Oort, 2005:25). Ook O'Donnell (2005:44,49) oordeel dat Augustinus sy lewe as Manicheër minimaliseer (vgl. breedvoerig Lieu, 1992). 
In die Christelike lewe is drie fundamentele en onmisbare elemente, naamlik geloof, hoop en liefde. Daarsonder is geen Christelike spiritualiteit moontlik nie. Hieroor het die kerkvader geskryf in Handboek (ench.).

\section{- 'n Spiritualiteit van geloof}

Ek begin met die tema van geloof - die ware spirituele lewe word gekarakteriseer deur geloof. Dit is 'n spiritualiteit van geloof - wat eintlik dieselfde is as om te sê 'n spiritualiteit van genade. Geloof moet in hierdie verband verstaan word as vertroue in God, wat vertroue in die drie-enige God beteken soos die kerkvader dit in sy boek De Trinitate (trin.) breedvoerig sou uiteensit.

Augustinus vind in die Christologie die ontsluiting van die Godsleer: die ware en vaste fondament van die katolieke geloof is Christus (ench. 16:5). Juis hiérdie Naam het hy in die platoniese geskrifte baie gemis (conf. $3.4 ; 5.14 ; 7.18,21$ )!

Daar kan egter nie van geloof sprake wees sonder genade nie - en van genade ook nie sonder sonde ${ }^{9}$ nie. Augustinus se genade- en sondeleer is diepgaande deur die "teologie" van Paulus, en veral die Romeinebrief, beïnvloed (Gilson, 1960:235-244; TeSelle, 1970:185). Uiteindelik is die geloof wat God vra, 'n geskenk wat Hy deur sy Gees gee (Rom. 9:16; civ. Dei 10.22; 14.1, 23, 26, 27; 15.1, 3, 18). Die genade (gratia) is verniet (gratis) (sermo spec. 224; vgl. Wijdeveld, 1986:87). Want "wat besit jy wat jy nie ontvang het nie?" (1 Kor. 4:7) - 'n telkens herhaalde teks (vgl. conf. 13.14). Op grond hiervan kom sy bekende uitspraak: "Gee wat $U$ beveel en beveel wat U wil"10 - 'n uitspraak wat Pelagius hartstogtelik verwerp het.11

Wat die inhoud van hierdie geloof behels, verwys die biskop in 'n preek (sermo spec. 213; vgl. Wijdeveld, 1986:22) na die Symbolum, wat 'n effens verkorte weergawe van die bekende Apostolicum bevat.

Die geloof gaan uiteindelik oor in aanskouing en daarom gee Augustinus ook aandag aan die visio Dei. Die verlostes sal God eenmaal

$9 \quad$ Vergelyk hoe breedvoerig (en vroeg) Augustinus die sonde in sy Enchiridion ter sprake bring $(26,46-48,78-80,83)$.

11 Vergelyk Lancel (2002:326): "Pelagius ... launched into an impassioned refutation". 
sien, egter nie met die liggaamlike oog nie, maar met die geestelike oog (acies mentis) (sermo spec. 53.6/7; vgl. Wijdeveld, 1986:139). Hierdie geestelike sien benodig egter reiniging om God te sien, sowel in hierdie lewe as in die toekomstige (trin. 15.21-23; vgl. Hill, 1997:411-415). Dit is juis die geloof wat hierdie reiniging bewerk.

\section{- $\quad$ 'n Spiritualiteit van hoop}

'n Tweede aspek wat genoem kan word, is hoop. Die spiritualiteit van Augustinus kan getipeer word as 'n spiritualiteit van hoop. Hierdie aspek word woordryk verwoord veral in Augustinus se magistrale werk De civitate Dei (413-427). Hierin weerlê hy in die eerste tien boeke die valse beskuldigings van die heidene wat die val van Rome in 410 aan die leerstellings van Christene toegeskryf het. In boeke 11-22 bied hy 'n positiewe uiteensetting van die Christelike geloof aan die hand van die twee stede wat (deureengevleg) in die wêreld gevind word: die stad van God (civitas Dei) en die aardse stad (terrena civitas). Hiermee bied die kerkvader 'n grootse ontwerp van 'n teologie van die geskiedenis, van die koninkryk en hoop.

Dit is waar dat die twee stede deur twee soorte liefde gevorm word: die aardse stad deur selfliefde (met minagting van God) en die hemelse stad deur liefde tot God (met minagting van die self) (civ. Dei 14.13, 28; 15.3). Dit gaan ook oor twee maniere van glo en hoop. Die aardse stad is op selfliefde (amor sui), begeerte (cupiditas) en hoogmoed (superbia) gebou; kenmerke wat uitdrukking in dominasie en magslus (libido dominandi) vind. Daarteenoor word die stad van God deur geloof, hoop en liefde gekarakteriseer.

Augustinus was diep bewus van die voorlopigheid en verganklikheid van hierdie lewe; dat die mens 'n vreemdeling op aarde is, 'n pelgrim op weg na 'n groter vaderland, die nuwe hemel en die nuwe aarde (civ. Dei 19.17).12 'n Burger van die stad van God maak dus slegs van die aardse goed "gebruik" (uti), maar "geniet" (frui) net God en sy ryk. ${ }^{13}$ Die hele lewe van 'n egte Christen is een heilige verlange na (en gebed om) alles wat God belowe het (Schrama, 1999:217, 219, 235).

Die Christelike hoop hou die wêreld gaande!

12 Vergelyk ook in hierdie verband Augustinus se roerende gesprek met sy moeder oor die koninkryk van die hemel by Ostia buite Rome (conf. 9.10).

13 Vir 'n breedvoerige bespreking van uti en frui by Augustinus, vergelyk Van Wyk (2001:106-132). 


\section{- $\quad$ 'n Spiritualiteit van liefde}

'n Derde - en deurslaggewende - faset wat die spiritualiteit van Augustinus kenmerk, is dat dit ' $n$ spiritualiteit van liefde genoem kan word. Hy kan met reg "teoloog van die liefde" genoem word. Daar is vir hom niks hoër, niks dieper, niks breër, ja, niks beter of belangriker as die liefde (caritas) nie (vgl. Van Wyk, 2005:349 vir verdere bronverwysings). Katkisante moes van jongs af leer dat die vernaamste rede vir die koms van Christus daarin geleë is dat God sy liéfde vir ons wou toon (cat. rud. 4.7; Mausbach, 1909, 1:168-221). Liefde dien ook as hermeneutiese sleutel om die Skrif te verstaan (doc. Chr. 3.15, 23). Liefde kan gedefinieer word as daardie aktiwiteit van die siel om God ter wille van Homself te geniet en die genieting van jouself en jou naaste ter wille van God (doc. Chr. 3.10, 16). Ons grootste vreugde bestaan egter in die genieting van God drie-enig (trin. 1.8.18). Goeie mense gebruik die wêreld om God te geniet en slegte mense gebruik God om die wêreld te geniet (civ. Dei 15.7). Tereg kan gepraat word van 'n "spiritualiteit van geniet" (Schrama, 1999:226, 231).

Dit is vir die biskop belangrik om van geordende liefde te praat. Eerstens kom die liefde tot God, daarna tot die mens terwyl dit nog bemiddel word deur die liefde tot God (civ. Dei 15.22). 'n Mens mag nie die Absolute relatief liefhê en die relatiewe absoluut nie. Dit kan verstaan word as: "sê my wat jy liefhet en ek sal jou sê wie jy is". Liefde is die gewig wat alles orden (conf. 13.9).

Ware godsdiens bestaan nie in toorn, nepotisme en haat nie, maar in liefde (inklusief vyandsliefde) en die navolging van God (sermo 7.4; vgl. Van Bavel, 1996:49). Daar is geen moeiliker voorskrif as om die vyand lief te hê nie (sermo 9.3; vgl. Van Bavel, 1996:59).

Augustinus het 'n pragtige preekkommentaar op 1 Johannes (ep. Jo.) geskryf wat eintlik as 'n loflied op die liefde beskou kan word. Enkele van sy bekende uitsprake is die volgende:

- "soos wat 'n mens liefhet, so ís jy ook" (2.14);

- "liefde is die skoonheid van die siel" (10.9);

- "die liefde is die voltooiing van al ons werke; dit is die eindpunt; daarom het ons op weg gegaan; daarna is ons op weg; as ons die liefde bereik het, sal ons rus vind" (10.4);

- "het lief en jy sal niks anders as goed doen nie" (10.7); 
- "die beoefening van die liefde, haar krag, haar bloei, haar vrugte, haar skoonheid, haar sjarme, haar voedsel, haar drank, haar spys en haar omhelsing, ken geen versadiging nie" (10.7).

In hierdie paaspreke kritiseer die biskop ook die Donatiste wat van die Katolieke Kerk weggebreek het - nie oor dogmatiese verskille nie (vgl. Frend, 1952). Wie die eenheid van die kerk verbreek, al is dit met goeie bedoelings (bv. ter wille van die smetloosheid en heiligheid van die kerk), handel liefdeloos. "Van die Donatiste byvoorbeeld kan 'n mens onmoontlik sê dat hulle liefde besit, aangesien hulle die eenheid van die kerk verskeur het" (ep. Jo. 6.2).

Dis binne hierdie konteks dat Augustinus sy beroemde uitspraak gemaak het: "Het lief en doen wat jy wil" (ep. Jo. 7.8).14 Christene moet immers álle mense, ook opponente en selfs vyande, liefhê. Dit geld ook van Katolieke Christene teenoor Donatiste.

Die kritiese vraag moet hier gestel word of Augustinus die toets slaag wat hy hier aangelê het. Uiteindelik het hy, ná die groot Kartaagse Konferensie met die Donatiste in 411, van die standpunt uitgegaan dat staatsdwang geoorloof is om Katolieke te beskerm en dat Donatiste tot katolisisme gedwing mag word (Luk. 14:23) - selfs al moet toegegee word dat Augustinus oor ' $n$ periode van tien jaar deur middel van debatte, korrespondensie en boeke die Donatiste probeer oorreed het om by die Katolieke Kerk in te skakel (vgl. Rist, 1999:240, 243). Dit is opvallend dat Augustinus in sy Retractationes (retr. 2.5) sê dat dit nie sy wens was om die skeurmakers met staatsgeweld te laat terugdwing nie (vgl. Frend, 1952:240).

In verband met die liefdespiritualiteit van die kerkvader, kan ook na sy huweliks- en seksuele etiek verwys word - seker een van die mees omstrede aspekte van sy hele teologie en spiritualiteit (vgl. Van Wyk, 2002a:327-348). Die wyse waarop hy seksuele begeerte en sonde met mekaar in verband gebring het, selfs binne die huwelik (al was dit dan as "vergeefbare sonde"), kan sekerlik nie die toets van 'n skriftuurlike huweliksetiek deurstaan nie.

'n Besondere uiting van liefde was vir Augustinus ook te vind in vriendskap. Die biskop was werklik nooit sonder vriende nie. Hy was altyd omring deur 'n wye vriendekring waaronder Romanianus, $\mathrm{Ne}$ bridius (jonk oorlede), Alypius, Evodius en Possidius (vgl. Brown, 1969:61-64; Van Bavel, 1970:23-36; Lancel, 2002:43, 484; O’Don- 
nell, 2005:101-106). Volgens Lienhard (1999:272-273; vgl. civ. Dei 19.8) was Augustinus die eerste Christelike skrywer wat 'n teorie oor vriendskap ontwikkel het en in sy Confessiones bring hy hierdie tema herhaaldelik ter sprake (conf. 4.3-4.9). Augustinus aanvaar aanvanklik die definisie van Cicero, om dit egter later christologies en pneumatologies te verdiep. Vriendskap bestaan nie net in 'n eens-wees oor menslike en goddelike sake met gepaardgaande welwillendheid en liefde nie (volgens Cicero), maar eens-wees in Christus deur die liefde wat die Heilige Gees gee. Vriendskap word gedra deur liefde, trou, eerlikheid en welwillendheid (Schrama, 1999:164-181).

Liefde vind ook uitdrukking in gasvryheid. Augustinus is die enigste pastor (aan my) bekend wat die armes van die stad na elke verjaarsdagete uitgenooi het (vgl. sermo spec 339; vgl. Wijdeveld, 1986:164,206), asook na die herdenking van sy wyding (Van der Meer, 1949:262; Brown, 1969:198). Hy het ook van die Katolieke verwag om die Donatiste (tydens die groot konferensie van 411) gasvry te ontvang (Schrama, 1999:152-163).

\section{- 'n Spiritualiteit van geluk}

Vierdens is die spiritualiteit van die kerkvader gestempel deur die motief van geluk. Dit kan omskryf word as 'n spiritualiteit van geluk. 'n Mens sou ook hiermee kon begin het, aangesien die tema van geluk reeds by die jong Augustinus ' $n$ belangrike rol gespeel het. Marrou noem die vraag na geluk selfs die "sentrale probleem" in die denke van Augustinus (Marrou, 1981:151; vgl. Mausbach, 1909, 1:51-84; Schrama, 1999:80, 86; Rist, 1999:48-53).

Augustinus wys telkens daarop dat alle mense daarna streef om gelukkig te wees (b. vita 2.10; vgl. verder conf. 10.20-23; sermo Car. 150; vgl. Wijdeveld, 1988:69; sermo 1.1; vgl. Van Bavel, 1996:26; Harrison, 2000:79), soos Cicero in sy Hortensius aanvoer. Die groot vraag is egter wat ware geluk is en waar dit gevind word. Die sentrale vraag tydens sy kort verblyf in Cassiciacum buite Milaan ná sy bekering was wat 'n gelukkige lewe is (Lancel, 2002:176). ${ }^{15}$ Teen die skeptici voer Augustinus aan dat hulle nooit geluk sal vind nie, omdat hulle ontken dat waarheid gevind kan word. Net wie die ewige en blywende God besit, kan gelukkig wees (b. vita 2.11); slegs kennis van die ware God bring geluk in die lewe (conf. 5.4, 10.20); elkeen is gelukkig wat 'n genadige God besit (b. vita 3.19). 
Ware geluk is geleë in die besit van die wysheid van God en ware Wysheid is die Seun van God (b. vita 4.33, 34).16 Ware geluk bestaan dus daarin om God en Jesus Christus te ken (Joh. 17:3; Gilson, 1960:9). Ongelukkig is die mens wat alles ken, maar nie God nie; gelukkig is die mens wat God ken, ook al ken hy nie alle feite nie (conf. 5.4). Die kerkvader weerlê daarom in die eerste tien boeke van die De civitate Dei die heidense gedagte dat 'n mens ín en ná hierdie lewe geluk kan vind deur afgode te dien.

In een van sy preke vind ons hierdie pragtige beskrywing (eintlik gebed) van wat ware geluk eintlik is:

Heer mijn God, Heer onze God, maak ons gelukkig door U, zodat wij tot $U$ komen. Wij willen niet gelukkig worden door goud, door zilver of door landgoederen. Niet door dat aardse bezit, door leugens en de vluchtigheid van een vergankelijk leven. Laat onze mond geen leugens verkondigen. Maak ons gelukkig door Uzelf, want $U$ zullen we niet verliezen. Als wij $U$ bezitten, kunnen wij $U$ niet verliezen en gaan wij niet verloren. Maak ons gelukkig door Uzelf, want gelukkig is het volk waarvan de Heer God is. (sermo 113.6; vgl. Gehlen-Springorum et al., 2002:199.)

Die gelukkige lewe bereik sy volmaaktheid deur aksie en kontemplasie (s. Dom. mon. 2.71; vgl. Wenneker \& Van Reisen, 2000:178; Schrama, 1999:135-151). Die hoogste geluk bestaan in die ewige lewe, sonder vrees en sonder dwaling (sermo Car. 150.10; vgl. Wijdeveld, 1988:76).

Hierdeur vind die soekende mens nie alleen geluk nie, maar ook ware rus, want God het die mens geskape tot Hom: "ons hart is onrustig tot dit rus vind in U" (conf. 1.1).17 In hierdie waarheid moes katkisante van jongs af onderrig word (cat. rud. 17.27; vgl. Wijdeveld, 1982:51).

Daar bestaan vir Augustinus egter geen geluk sonder egte vroomheid nie. Egte vroomheid bestaan in die verering van die ware God

16 In sy proefskrif voer Couvee (1947:264-265) aan dat die begrip vita beata in Augustinus se latere werke steeds 'n meer teologiese en eskatologiese invulling ontvang en dat hy sodoende die filosofiese invloede oorwin het.

17 Et inquietum est cor nostrum, donec requiescat in te. Die vrede van alle dinge bestaan vir Augustinus (civ. Dei 19.13) in die rus van 'n geordende lewe: liggaamsdele wat saamwerk met die volle liggaam, die liggaam met die siel, die mens met God en mense met mense in geordende eendrag. 
(civ. Dei 4.23). Die biskop waarsku dus telkens in sy geskrifte en preke teen bepaalde dinge waarby, volgens hom, 'n Christen nie betrokke behoort te wees nie soos dobbel, toneel, kroeg, bordeel, teater, drankmisbruik, hebsug, bedrog, egbreuk, hoerery en sterrewiggelary (cat. rud. $7.11 ; 16.25 ; 25.48 ; 27.55) .{ }^{18} \mathrm{Hy}$ het veral sterk teen teaterbesoek gewaarsku (sermo 198.9; vgl. Van Zaalen et al., 2001:53; sermo 114B.16; vgl. Gehlen-Springorum et al., 2002:247; Van der Meer, 1949:621), vanweë die voorwerpe wat uit die heidense mitologie vertoon word en die opgevoerde obseniteite. 19

Wie gelukkig en rustig wil lewe, moet in gemeenskap met God en die medemens lewe.

\section{- $\quad$ 'n Spiritualiteit van waarheid}

'n Vyfde aspek wat ter sprake kom, is waarheid. Die spiritualiteit van die kerkvader kan ook bestempel word as 'n spiritualiteit van waarheid. Die geluksalige lewe is vir Augustinus 'n lewe van vreugde oor die waarheid, dit wil sê 'n vreugde oor God (conf. 10.23). Waarheid en geluk vorm vir hom 'n onlosmaaklike eenheid. Voeg waarheid by jou lewe en jy het geluk; net die waarheid maak immers gelukkig (Burnaby, 1938:153; Gilson, 1960:3). Sonder geloof kan niemand egter die waarheid vind nie.

Van sy vroegste geskrifte af, byvoorbeeld Contra Academicos (386), tot in sy latere werke wys die kerkvader die skeptisisme af en vind hy die summa veritas in God en in die Woord van God, geskenk deur die Heilige Gees (conf. 10.24; 13.31).

Dit is daarom geen wonder nie dat die biskop hom sterk uitspreek teen alle vorms van leuens en dat hy álle leuens, sonder uitsondering, moreel ongeoorloof vind (vgl. ench. 16-22). 20 Hierdie radikale standpunt het meegebring dat hy nie 'n moreel-aanvaarbare antwoord op die vraagstuk van die "noodleuen" kon ontwikkel nie.

Dit is waar dat die Neoplatoniese ideëleer 'n groot invloed op Augustinus se waarheidsbeskouing uitgeoefen het, maar in sy latere werke ontwikkel hy sy denke veel meer teologies en christologies. Die altyd wyn aan tafel laat bedien (vgl. Possidius, 1988:91, 92; Vita 22.2). 
Waarheid, wat alle waarheid moontlik maak, is onsterflik en onverganklik en ten diepste identies aan Christus, aan God.

Dit is sonder meer duidelik dat die waarheid/Waarheid vir Augustinus in die Skrif te vind is (soos hy dit in die Latynse tekste tot sy beskikking gehad het) - selfs al het hy nooit 'n volledige Bybel voor hom gehad soos ons dit vandag ken nie (O'Donnell, 2005:127). In hierdie verband moet na die kerkvader se Skrifleer verwys word waarin hy die Skrif as betroubare en gesaghebbende bron aanvaar en benut. Dis is egter 'n onderwerp wat ons te ver van ons sentrale ondersoek sal wegvoer. 21 Genoeg om te sê dat 'n mens Augustinus tereg 'n Skrifteoloog sou kon noem.

\section{- $\quad$ 'n Spiritualiteit van nederigheid}

'n Sesde en laaste aspek wat hier genoem moet word, is nederigheid: die spiritualiteit van Augustinus kan beskryf word as 'n spiritualiteit van nederigheid (vgl. veral Schaffner, 1959). Nederigheid is vir hom 'n basisdeug, 'n deug van alle deugde, en dit blyk veral uit sy Reël vir gemeenskap (Regula: Praeceptum, 397; reg.). Hieruit blyk nie alleen hoe belangrik daaglikse gebed, sang en Skriflesing is nie, maar watter belangrike rol nederigheid, liefde en gemeenskap in die Christelike lewe speel, in teenstelling met hebsug, mag en hoogmoed. 22

Daar is tereg opgemerk dat Augustinus se groot ontdekking die betekenis van nederigheid was. Daarmee saam die sonde van hoogmoed en dat geluk net te vind is waar die verstand sigself aan geloof en 'n behoefte aan genade onderwerp (Gilson, 1960:227). Nederigheid en hoogmoed is antitetiese begrippe.

Die begin van alle sonde is hoogmoed en die begin van hoogmoed is ontrou aan God (s. Dom. mon. 1.32; vgl. Wenneker \& Van Reisen,

21 Vir 'n kort samevatting van Augustinus se Skrifleer, vergelyk Van Wyk (2002b:593-601) asook Brock (2007:99-164).

22 Vergelyk Van der Meer (1949:273). Vergelyk hierteenoor die kritiese opmerking van O'Donnell (2005:36) wat die Confessiones nie as 'n boek van nederigheid beskou nie, maar van selfverheerliking. Van Geest (2002) het 'n konstruktiewe bydrae oor die spiritualiteit van Augustinus gelewer, met uitgebreide aandag aan Augustinus se stryd met die Donatiste. Persoonlik sou ek nie Augustinus se integriteit "als weg naar God" omskryf nie, maar eerder as "gawe van God" - op grond van die kerkvader se genadeleer. Vergelyk ook Van Geest (2002:14) se uitspraak: "Een mens ís, niet omdat hij denkt, maar omdat hij is afgestemd op de golflengte van de genade." 
2000:81; sermo 198.33; vgl. Van Zaalen et al., 2001:79). Geluk begin by nederigheid (s. Dom. mon. 1.10; vgl. Wenneker \& Van Reisen, 2000:61).

Daar bestaan vir Augustinus geen twyfel nie dat hoogmoed die oorsprong en hoogste uitdrukking van sonde is (Van Bavel, 1970: 43). Hoogmoed as perverse imitasie van God, is die begin van alle sonde en dit mond uit in magswellus (libido dominandi) (Markus, 1988:xvii). Perverse selfliefde gegrond in hoogmoed, is die fundamentele wanorde in die individu en in die samelewing (Markus, 1988:xviii).

Wanneer die kerkvader se karakter beskryf word, word op die volgende fasette gewys: fyngevoelig, begrypend maar "doorzetter", intellektueel, vryheidsmens, soms te veel gesteld op verworwe beginsels (Van Bavel, 1970:133); oorsensitief (Lancel, 2002:261); flegmaties (O’Donnell, 2005:120; vgl. 315-330).

Dit is dus merkwaardig dat 'n kerkvader met soveel begaafdhede en iemand wat in sy eie tyd reeds soveel bekendheid en beroemdheid verwerf het - aldus Hieronimus (vgl. Rist, 1999:290; TeSelle, 1970: 341) - soveel klem gelê het op nederigheid as Christelike deug. Dit is egter welbewus gedoen in navolging van Jesus Christus wat Homself ter wille van ons verneder het.

\section{Uitleiding}

Samevattend sou die spiritualiteit van Augustinus getipeer kon word as 'n spiritualiteit van integriteit. "The spirituality Augustine lived and taught was nothing other than the integration of one's Christian beliefs with one's daily life." (Clark, 1999:815.) Tereg merk Clark (1999:815) verder op: "Augustine's own spiritual life comprised union with God, communion with his neighbours, and ministry to those in need of spiritual and material assistance."

Ons konklusie wys in dieselfde rigting. Die spiritualiteit van Augustinus is diepgaande gestempel deur geloof (genade), hoop en liefde, deur sy soeke na geluk en na waarheid en deur sy beklemtoning van nederigheid. 23

23 Ons sou hier ook kon spreek van 'n spiritualiteit van vryheid, met verwysing na Augustinus se denke oor die vrye wil en sy pelagiaanse stryd, maar ruimte ontbreek daarvoor (vgl. ook Augustinus, mor.). 
Anders gesê: die spiritualiteit van Augustinus word deur die volgende gekenmerk: 'n lewe in gemeenskap met God; 'n lewe in navolging van Christus; 'n lewe onder leiding van die Gees; 'n lewe in die lig van die Skrif; 'n lewe in diens van die koninkryk; 'n lewe tot opbou van die kerk; 'n lewe tot welsyn van die medemens en die samelewing; en 'n lewe van persoonlike meditasie en aksie.

Ons ontdek by die kerkvader 'n deurleefde religieuse identiteit en 'n outentieke en integrale spiritualiteit.

Die vraag dring hom vanself aan ons op of ons dan by Augustinus te doen het met 'n volkome vlekvrye spiritualiteit. Die antwoord is: Sekerlik nie. Dit kan gemotiveer word deur slegs twee aspekte te noem: eerstens kan die wyse waarop sy verhouding met sy konkubine, vir wie hy so innig lief was (conf. 6.15), beëindig is, bevraagteken word. Wills (1999:41) stel dit: "There is no way to excuse Augustine's treatment of Una."24 Tweedens is die biskop se (uiteindelike) optrede teen die Donatiste (waar hy staatsdwang, weliswaar teësinnig, geregverdig het) verklaarbaar, maar teologies nie verdedigbaar nie (Van Geest, 2002:30).25 So 'n standpunt is immers onversoenbaar met die evangelie van Christus wat 'n evangelie van vryheid is en waar oortuiging in plaas van dwang, bepalend vir kerkwees is.

Die spiritualiteit van die kerkvader sou getipeer kon word as 'n "spiritualiteit van kyk" (gedagtig aan Matt. 6:22): opkyk na God, rondkyk na jou medemens(-e), inkyk in jou eie hart, en uitkyk na die koms van die koninkryk van God.

Augustinus was 'n ewige soeker na waarheid, rus en geluk. Uiteindelik het die rustelose soeker die genade van God in Jesus Christus gevind wat die Gees ons gee. Dis die essensie van Christelike spiritualiteit.

24 "Una" is 'n naam wat Wills (1999:16) geskep het (uit unam habebat). Haar naam is egter onbekend. Sy is van Milaan na Afrika teruggestuur en Augustinus het daarna (klaarblyklik) alle kontak met haar verbreek. Vergelyk ook Sizoo (s.a.:140): "Toch is deze geschiedenis een zwarte bladzijde uit Augustinus' leven."

25 Rist (1999:231) stel tereg die vraag waarom Augustinus geswyg het oor die gebruik van staatsgeweld teen die Manicheërs. 


\section{Geraadpleegde bronne}

\section{Lys van Augustinus se boeke26}

b. vita: De beata vita (386/387). Ferwerda, R., vert. 1999. Augustinus: over het gelukkige leven. Baarn: Agora.

cat. rud.: De catechizandis rudibus (399). Wijdeveld, G., vert. 1982. Augustinus: Het eerste geloofsonderricht. Baarn: Ambo.

civ. Dei: De civitate Dei (413/427). Dods, M., vert. 1949. The works of Aurelius Augustine, Bishop of Hippo: The city of God. Vol. 1 \& 2. Edinburgh: Clark.

conf.: Confessiones (397/401). Outler, A.C., ed. 2004. St. Augustine: the confessions. Peabody: Hendrickson.

doc. Chr.: De doctrina Christiana (396; 426/427). Robertson, D.W., vert. 1958. Saint Augustine: on Christian doctrine. New York: Macmillan.

ench.: Enchiridion ad Laurentium de fide spe et caritate (421/422). Paolucci, ed. 1987. St. Augustine: the Enchiridion on faith, hope and love. Washington: Regnery Gateway.

ep. Jo.: In epistulam Joannis ad Parthos tractatus (406/407). Van Bavel, T.J., vert. 1992. Preken over de eerste brief van Johannes. Leuven: Augustinus Historisch Instituut.

mor.: De moribus ecclesiae catholicae et de moribus Manichaeorum (387/388). Schaff, P., ed. 1979. Nicene and Post-Nicene Fathers of the Christian Church. Vol. 4. Grand Rapids: Eerdmans. p. 41-63, 69-89.

reg.: Regula Praeceptum (397/399). Van Bavel, T.J., vert. 1991. Augustinus van Hippo: regel voor de gemeenschap. Kampen: Kok.

retr.: Retractationes (426/427). Bogan, M.I., trans. 1968. Retractations. Washington: The Catholic University of America Press.

s. Dom. mon.: De sermone Domini in monte (393/395). Wenneker, L. \& Van Reisen, H., vert. 2000. Aurelius Augustinus: het huis op de rots verhandeling over de Bergrede. Amsterdam: Ambo.

sermo 1-32. Van Bavel, T.J., vert. 1996. Augustinus: commentaar op Psalm 118/119. Baarn: Ambo.

sermo 94a-367. Gehlen-Springorum, J. et al., vert. 2002. Als korrels tussen kaf: preken over teksten uit het Marcus- en Lucasevangelie. Amsterdam: Ambo.

sermo 189-378. Van Neer, J. et al., vert. 1996. Aurelius Augustinus: als licht in het hart - preken voor het liturgisch jaar. Baarn: Ambo.

sermo 198-376(A). Van Zaalen, R., Van Reisen, H. \& Van der Meijs, S., vert. 2001. Aurelius Augustinus: als lopend vuur - preken voor het liturgisch jaar, 2. Amsterdam: Ambo.

sermo Car. Wijdeveld, G., vert. 1988. Augustinus: Carthaagse preken. Baarn: Ambo. [Sluit o.a. preke 19-357 in.]

sermo spec. Wijdeveld, G., vert. 1986. Twintig preken van Aurelius Augustinus. Baarn: Ambo. [Sluit o.a. preke 9-339 in.]

26 Ter wille van duidelikheid en eenvoud verwys ek eerstens na (erkende) afkortings van die geskrifte van Augustinus, dan na die Latynse titel, daarna na die datering, en daarna na 'n vertaalde weergawe van daardie geskrif. In die teks self word hierdie volgorde (grotendeels) gevolg. 
trin.: De Trinitate (399-422/426). Hill, E., trans. 1997. Saint Augustine: the Trinity. New York: New City Press.

\section{Lys van ander boeke}

AUMANN, J. 1985. Christian spirituality in the catholic tradition. Londen: Ignatius.

BEUMER, J., red. 1990. Als de hemel de aarde raakt: spiritualiteit en mystiek. Kampen: Kok.

BROCK, B. 2007. Singing the ethos of God: on the place of Christian ethics in Scripture. Grand Rapids: Eerdmans.

BROWN, P. 1969. Augustine of Hippo: a biography. Berkeley: University of California Press.

BURNABY, J. 1938. Amor Dei: a study of the religion of St. Augustine. Londen: Hodder \& Stoughton.

CLARK, M.T. 1999. Spirituality. (In Fitzgerald, A.D., ed. Augustine through the ages: an encyclopedia. Grand Rapids: Eerdmans. p. 813-815.)

CONRADIE, E.M. 2006a. Waar op dees aarde vind mens God? Op soek na 'n aardse spiritualiteit. Wellington: Lux Verbi.BM.

CONRADIE, E.M. 2006b. Op soek na 'n aardse spiritualiteit. Nederduitse Gereformeerde teologiese tydskrif, 47(3 \& 4):373-383.

COUVEE, P.J. 1947. Een onderzoek naar de ontwikkeling van het begrip "beata vita" naast en tegenover "vita aeterna", bij Lactantius, Ambrosius en Augustinus, onder invloed der Romeinse Stoa. Baarn: Hollandia.

DE VILLIERS, P.G.R. 2008. Aanbidding van God in die lig van bybelse spiritualiteit. Nederduitse Gereformeerde teologiese tydskrif, 49(3 \& 4):124-139.

DE VILLIERS, P.G.R., KOURIE, C.E.T. \& LOMBAARD, C., eds. 2006. The Spirit that moves: orientation and issues in spirituality. Bloemfontein: University of the Free State.

DREYER, T.F.J. 1998. Spiritualiteit, identiteit en die etos van die Nederduitsch Hervormde Kerk. Hervormde teologiese studies, 54(1 \& 2):289-314.

FITZGERALD, A.D., ed. 1999. Augustine through the ages: an encyclopedia. Grand Rapids: Eerdmans.

FOERSTER, W. 1985. Eusébeia. (In Kittel, G. \& Friedrich, G., eds. Theological Dictionary of the New Testament. Trans. by G.W. Bromiley. Grand Rapids: Eerdmans. p. 1010-1014.)

FREND, W.H.C. 1952. The Donatist Church: a movement of protest in Roman North Africa. Oxford: Clarendon.

GILSON, E. 1960. The Christian philosophy of Saint Augustine. New York: Random House.

HARRISON, C. 2000. Augustine: Christian truth and fractured humanity. Oxford: Oxford University Press.

HOLMES, U.T. 1981. A history of Christian spirituality: an analytical introduction. New York: Seabury.

HOWARD, E.B. 2008. The Brazos introduction to Christian spirituality. Grand Rapids: Brazos.

JONES, C., WAINWRIGHT, G. \& YARNOLD, E., eds. 1986. The study of spirituality. Londen: SPCK.

JONKER, W.D. 1989. Die eie-aard van gereformeerde spiritualiteit. Nederduitse Gereformeerde teologiese tydskrif, 30(3):288-299. 
KOURIE, C. \& KRETZSCHMAR, L., eds. 2000. Christian spirituality in South Africa. Pietermaritzburg: Cluster.

KRETZSCHMAR, L. 1996. A holistic spirituality: a prerequisite for the reconstruction of South Africa. Journal of theology for Southern Africa, 95:63-75.

LANCEL, S. 2002. St. Augustine. Trans. by A. Nevill. Londen: SCM.

LIENHARD, J.T. 1999. Friendship, friends. (In Fitzgerald, A.D., ed. Augustine through the ages: an encyclopedia. Grand Rapids: Eerdmans. p. 272273.)

LIEU, S.N.C. 1992. Manichaeism in the later Roman Empire and Medieval China: a historical survey. Tübingen: Mohr.

LOMBAARD, C. 2009. What is biblical spirituality? Perspectives from minor genre of Old Testament scholarship. Journal of theology for Southern Africa, 135:85-99.

LOUW, D.J. 2005. Geloofsvolwassenheid en Christelike spiritualiteit binne die knyptang van prestasiedruk tydens vroegbejaardheid. In die Skriflig, 39(3):423-439.

MARIS, J.W. 1994. Schepping en verlossing - het kader van een bijbelse spiritualiteit. Kampen: Kok.

MARKUS, R.A. 1988. "Saeculum": history and society in the theology of St. Augustine. Cambridge: Cambridge University Press.

MARROU, H-I. 1981 [1938]. Augustinus und das Ende der antiken Bildung. Paderborn: Ferdinand Schöningh.

MAUSBACH, J. 1909. Die Ethik des heiligen Augustinus. TI. 1 \& 2. Freiburg im Breisgau: Herdersche Verlagshandlung.

McGRATH, E. 1999. Christian spirituality. Oxford: Blackwell.

NICOL, W. 2002. Gebed van die hart: word stil en beleef God. Wellington: Lux Verbi.BM.

NOLAN, A. 1982. Biblical spirituality. Springs: Order of Publishers.

O'DONNELL, J.J. 2005. Augustine, Saint and sinner: a new biography. Londen: Profile Books.

OOSTENBRINK, J.W. \& LOTTER, G.A. 1999. Gereformeerde spiritualiteit as korporatiewe spiritualiteit. In die Skriflig, 33(3):367-383.

PANNENBERG, W. 1986. Christliche Spiritualität: theologische Aspekte. Göttingen: Vandenhoeck \& Ruprecht.

POSSIDIUS, 1988. The life of Saint Augustine. Ed. by J.E. Rotelle. Villanova: Augustinian Press. (afk. vita.)

RAMEY, R.H. \& JOHNSON, B.C. 1992. Living the Christian life: a guide to reformed spirituality. Louisville: John Knox.

RICE, H.L. 1991. Reformed spirituality: an introduction for believers. Louisville: John Knox.

RIST, J. 1999. Augustine: ancient thought baptized. Cambridge: Cambridge University Press.

SCHAFFNER, O. 1959. Christliche Demut. Des HI. Augustinus Lehre von der Humilitas. Würzburg: Augustinus Verlag/Verlag "Der Christliche Osten".

SCHRAMA, M. 1999. Augustinus: de binnenkant van zijn denken. Zoetermeer: Meinema.

SIZOO, A. s.a. Toelichting op Augustinus' belijdenissen. Delft: Meinema.

SMIT, D.J. 1988. Wat is gereformeerde spiritualiteit? Nederduitse gereformeerde teologiese tydskrif, 29(2):182-193. 
SMIT, D.J. 1989. Kan spiritualiteit omskryf word? Nederduitse gereformeerde teologiese tydskrif, 30(1):83-92.

SNYMAN, S.D. 1997. Spiritualiteit - 'n perspektief uit die Ou Testament. In die Skriflig, 31(4):1-13.

TeSELLE, E. 1970. Augustine the theologian. Londen: Burns \& Oates.

VAN BAVEL, T.J. 1970. Augustinus: van liefde en vriendschap. Baarn: Het Wereldvenster.

VAN DEN BERG, A. \& SÜSS, R. 2006. Spiritualiteit in Jodendom en Christendom. Heerenveen: Protestantse Pers.

VAN DER MEER, F. 1949. Augustinus de zielzorger: een studie over de praktijk van een kerkvader. Utrecht: Het Spectrum.

VAN DER WALT, J.L. 2009. Spirituality: the new religion of our time? In die Skriflig, 43(2):251-269.

VAN DER ZWAAG, K. 1993. Augustinus: de kerkvader van het Westen. Leiden: Groen.

VAN GEEST, P. 2002. Integriteit als weg naar God: over de spiritualiteit van Augustinus. Utrecht: KTU.

VAN OORT, J. 2005. Van Vergilius en Mani tot de Catholica: Augustinus' oorspronklike spiritualiteit. (In Van Geest, P. \& Van Oort, J. Augustiniana Neerlandica: aspecten van Augustinus' spiritualiteit en haar doorwerking. Leuven: Peeters. p. 11-29.)

VAN 'T SPIJKER, W., red. 1993. Spiritualiteit. Kampen: De Groot Goudriaan.

VAN WYK, J.H. 2001. Etiek en eksistensie - in koninkryksperspektief. Potchefstroom: Potchefstroomse Teologiese Publikasies.

VAN WYK, J.H. 2002a. Venialis culpa? Augustinus oor huwelik en seksualiteit. In die Skriflig, 36(3):327-348.

VAN WYK, J.H. 2002b. Fundamentalisme en kritisisme: nadenke oor Skrifbeskouing en Skrifverklaring - van Augustinus tot Bultmann. In die Skriflig, 36(4):593-620.

VAN WYK, J.H. 2005. Christelike identiteit: Augustinus oor geloof, hoop en liefde. (In Van Geest, P. \& Van Oort, J. Augustiniana Neerlandica: aspecten van Augustinus' spiritualiteit en haar doorwerking. p. 341-354.)

VAN WYK, J.H. 2008. Spiritualiteit en integriteit: teologies nagedink oor enkele aspekte van die spiritualiteit van Augustinus. (In Baars, A., Den Hertog, G.C., Huigen, A. \& Peels, H.G.L. Charis: theologische opstellen, aangeboden aan prof. dr. J.W. Maris. Heerenveen: Groen. p. 254-266.)

VELEMA, W.H. 1990. Nieuw zicht op gereformeerde spiritualiteit. Kampen: Kok.

VENTER, C.J.H. 1998. Spiritualiteit in die lig van Romeine 12. In die Skriflig, 32(4):457-468.

WAAIJMAN, K. 2000. Spiritualiteit: vormen, grondslagen, methoden. Gent: Carmelitana.

WILLS, G. 1999. Saint Augustine: a penguin life. New York: Viking Penguin.

\section{Kernbegrippe:}

Augustinus

Pietas

praxis pietatis

spiritualiteit

spiritualiteit, karakteristieke van 


\section{Key concepts:}

Augustine

Pietas

praxis pietatis

spirituality

spirituality, characteristics of 
